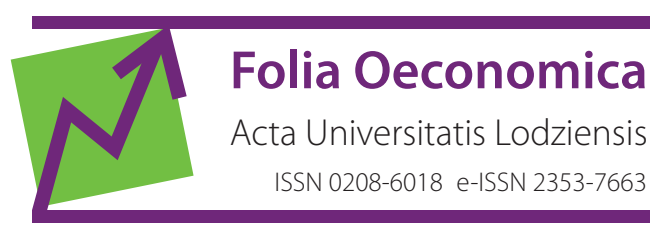

www.czasopisma.uni.lodz.pl/foe/

2(334) 2018

DOI: http://dx.doi.org/10.18778/0208-6018.334.07

\title{
Małgorzata Bartosik-Purgat
}

Poznań University of Economics and Business, Faculty of International Business and Economics,

Department of International Management, m.purgat@ue.poznan.pl

\section{M-communication in Product Information Exchange - an International Comparison ${ }^{1}$}

\begin{abstract}
The main objective of the paper is to identify the degree to which Social Networking Sites (SNSs) are used in communication related to gathering information about products via mobile devices (mobile communication). The research problem is presented in the context of Computer Mediated Communication theory (CMC). In the realisation of the main purpose of this paper, an attempt has been made to answer two research questions: firstly, is there a relationship between types of products and the frequency of gathering and conveying information about them via SNSs? Secondly, what role do mobile devices play in this communication? A comprehensive literature study has been complemented with an empirical research, conducted in four countries - China, Poland, the United States and Turkey. Two research methods: PAPI (Paper and Pen Personal Interview) and CAWI (Computer Assisted Web Interview) were used in the empirical research. The research showed a significant use of mobile devices (i.e. smartphones and tablets) in communication (gathering and conveying information about products) via SNSs, especially in relation to products such as electronic devices as well as clothes and footwear.
\end{abstract}

Keywords: Mobile Communication, Computer Mediated Communication theory, Social Networking Sites

JEL: M31, M37, M21

\footnotetext{
${ }^{1}$ Scientific grant no. 2015/17/B/HS4/00309 of National Science Centre, Poland.
} 


\section{Introduction}

The growth of technology has changed peoples' everyday lives. The development of business, marketing and electronics is user-directed (Lin, Lu, 2015). The growth of the Internet, and the possibilities it offers, play a significant role in the changes that are currently taking place. For example, Social Networking Sites (SNSs) enable fast and easy communication among people from even the most distant parts of the world (Carayannis, Clark, Valvi, 2012; Borrero et al., 2014). The development of mobile devices that are frequently used for this type of communication is constantly contributing to an even greater use of the Internet in various areas of life, e.g. gathering information in order to make purchasing decisions, improving knowledge levels, entertainment, and work (Borrero et al., 2014). The importance and the rapid growth of mobile devices can be seen when we compare it to the development of other communication forms in terms of the number of people that could be reached. After radio first appeared, it took 38 years for it to reach 50 million listeners. In the case of television it was only 13 years (Skokan, 2016). These inventions revolutionized the world and changed the way we live and they were certainly revolutions which, from the historical point of view, took place rapidly. However, in comparison to mobile technologies their pace was slow: it took only 7 years for mobile technology to reach 1.4 billion users (Skokan, 2016). The mobile revolution started when smartphones first appeared. Smartphone functions as both a phone and a computer and can be used at all times of the day and in many locations (Boateng, 2011; Tan, Goh, 2015). Due to these technological developments users have changed their behaviours and the growth of the importance of mobile technologies is a consequence of how users' needs have changed and how they will still continue to change (Persaud, Azhar, 2012). Indeed, the process is an ongoing one. The amount of time users spend using mobile technologies is high and yet still increasing (Suki, 2013; Kim et al., 2016). Data from 2016 shows that $51 \%$ of people worldwide use mobile devices, $27 \%$ use SNSs via mobile devices and there is a $17 \%$ year-on-year increase in SNSs use via mobile devices. The same report shows that 83\% of Facebook users access their accounts on mobile devices (Kemp, 2016).

The popularity and large scale of mobile device usages indicates new trends among users, which in turn can be effectively used by enterprises (Persaud, Azhar, 2012). One of these is the rejection of traditional usage patterns of desktop computers or laptops, which are usually used for working, online shopping, and paying bills. The needs of mobile device users are completely different. According to a number of studies (Carayannis, Clark, Valvi, 2012), the most important needs of such users are: finding new information as and when required, entertainment, and quick communication.

The main purpose of this paper is to identify the degree to which SNSs are used on mobile devices in communication related to gathering information about prod- 
ucts. The research problem is presented in the context of Computer Mediated Communication theory. Two research questions have been posed and answered: Firstly, is there a relationship between types of products and the frequency of gathering and conveying information about them via SNSs? Secondly, what role do mobile devices play in this type of communication? A literature study has been complemented with an empirical research, undertaken in four countries - China, Poland, the United States and Turkey. Analysis with the use of the Kruskal-Wallis test enabled identification of both similarities and differences among the surveyed respondents. The particular countries were chosen to represent the 'West' and the 'East'.

\section{Literature overview}

\subsection{Communication in the context of CMC theory}

Communication is the process of exchanging information between the sender and receiver through a specific channel (Davies, Musango, Brent, 2016). In interpersonal communication both sender and receiver are individuals exchanging a message via direct communication. In CMC theory the internet takes on the role of a medium in the interpersonal communication (Walther, 1996) and SNSs are internet tools used for communication amongst individuals who use that particular medium. They are not only able to write messages (e.g. Facebook and Twitter) but also listen to or record them (e.g. YouTube). The communication levels and types differ according to the chosen medium (Walther, 1996). CMC participants can transfer a message quickly, without direct cost and possibly to many receivers at the same time (Smith, Zook, 2011: 11). In CMC theory the use of SNSs reduces personal influence and its effects on the communication process as it is not direct, but through the medium of the Internet (Lin, $\mathrm{Lu}, 2015$ ). In relation to the context of this paper and CMC theory, both the sender and the receiver in the communication process are SNS users.

\subsection{SNSs as tools in Computer Mediated Communication}

Kaplan and Haenlein (2010) write that SNSs are sets of applications, technically and ideologically based on the foundations of Web 2.0. They enable the creation and exchange of content amongst their users. These key characteristics of SNSs are based on their function of connecting people and allowing the exchange of information about both private and professional lives.

The ways, means, and character of SNSs usage depends, first of all, on people's needs. For example, the need to share one's travel memories with friends may be met by using a website or a communicator such as Facebook, Instagram, Snap- 
chat, or writing a blog (Ryan, Xenos, 2011; Tan, Goh, 2015). SNSs which group people into networks of friends sharing common characteristics, were the first such media and are still popular among users, e.g. Facebook or LinkedIn. By using them users can look for other users who are able to provide particular information, or help search for it (Ray, 2014).

SNSs such as Facebook, YouTube or Twitter are also used for consumer purposes with regard to gathering and providing information about products and services (Habibi, Laroche, Richard, 2016; Erkan, Evans, 2016). There is a great amount of research on the significance of SNSs in users' sharing information about products and expressing opinions about brands (Wallace, Buil, De Chernatony, 2014). According to Kaplan and Haenlein (2011), in marketing theory, the method of gathering and exchanging information from informal sources (e.g. friends, family, neighbours) via the internet is called electronic Word of Mouth (e-WoM). In their paper they focus on communication and exchange of information about products among users via SNSs. E-WoM can be treated as a special type of CMC.

Up to now, there have been very few publications providing cross-cultural comparisons among SNSs users or presenting findings about the behaviours connected with the exchange of product information. Most studies are carried out by comparing individualistic and collectivistic countries because values represented by these opposing models may, to a significant degree, diversify SNS usage. For example, Andersen et al. (2007) have compared SNS usage among young Danes (individualism) and Koreans (collectivism). The Danes used mobile phones more often to access SNSs for entertainment purposes and communication, while Koreans mainly used SNSs for educational purposes. Another study by Fong and Burton (2008), which looked into e-WoM communication on Internet forums and creation of e-WoM messages, showed the differences between consumers from the United States (individualistic culture) and China (collectivistic culture). Their findings indicated that Americans more often convey information through e-WoM, whereas Chinese more often look for information rather than create it. The results of other projects also highlight differences in the way users who come from various cultural backgrounds use SNSs. In collectivistic countries SNS users focus on social interactions (building a network of friends, maintaining contacts with friends), while in individualistic countries SNS users concentrate more on personal development and finding information (Tsai, Men, 2012; Hsu et al., 2015).

The results of the presented research indicate differences amongst users from different countries in terms of using SNSs for communicating, as well as conveying and gathering information about products or services. Therefore, hypothesis $\left(\mathrm{H}_{1}\right)$ can be formulated, stating: SNSs are used in a variety of ways by the users from the researched countries, to communicate and exchange information about products. 


\subsection{Types of products which users exchange information about via SNS}

The methods of searching for information about products depend on their type. People do not search for information online about all products. Particularly significant differences can be observed between B2C and B2B markets. Internet users, including SNSs users, search for information about B2C products much more often. However, this field is under-researched. In paper by Hansen and Jensen (2009), it was found that Internet users most often looked for information about clothes, footwear and broadly defined accessories. Similar results have been obtained in recent studies by Geissinger and Laurell (2016) and Shephard et al. (2016). The products most often researched by consumers on the Internet are definitely more expensive. The purchase of such products obviously translates into spending a larger sum of money and so making a decision can take more time. The Internet thus seems to be a good source of information about particular types of products and brands, as well as a means of comparing them. In the case of FMCG (Fast Moving Consumer Goods) consumers make buying decisions quickly and do not need much information about them. Such findings have been published by one of the largest statistics portals, Statista, where the most popular types of products bought by Pinterest users were researched (Statista.com, 2012). The results of the research show that Pinterest users most often bought clothes (39\%), bags and jewellery (23\%) and works of art (22\%).

Taking into account the above research, it can be stated that SNSs users most often exchange information on electronic goods (computers, laptops, tablets, smartphones) as well as clothes and footwear. Stemming from this, hypothesis $\left(\mathrm{H}_{2}\right)$, states that: the frequency of exchanging information about products via SNSS is related to their type. Users most often exchange information via SNSS about electronic goods, clothes and footwear.

\subsection{Mobile SNS usage in the context of Computer Mediated Communication theory}

As recently as a few years ago, the main devices used for Internet access were desktop computers or laptops. Since then, the growth of technology has led to a significant change in the Internet (and therefore SNSs) accessing methods. First and foremost, this change regards the use of smartphones and tablets (Boateng, 2011). The number of people using mobile devices in the analysed countries (Figure 1) indicates their importance. In many of the presented markets (Spain, Italy, Japan) the number of mobile users amounts to over $80 \%$ of population (Kemp, 2016). The same study shows that SNS user levels are also high (Kemp, 2016). 


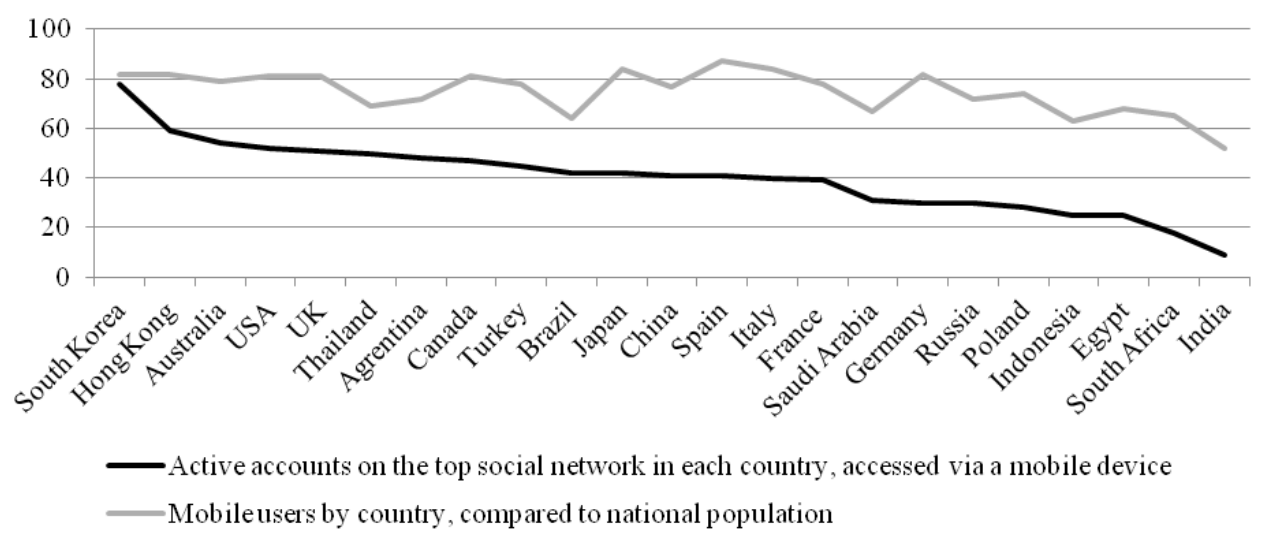

Figure 1. SNSs' and mobile usage Source: Kemp, 2016

What are the reasons for such a significance of mobile devices in the accessing of SNSs? The answer is related to the possibilities offered to users by these devices. The basic factor is the fact that they enable prompt reaction to the activity of other users and the use of media at any time and in any situation (Okazaki, Mendez, 2013). With smartphones people can not only communicate with others via phone calls or text messages (Tojib, Tsarenko, 2012; Suki, 2013; Kim et al., 2016; Tan, Goh, 2015) but can also watch films and TV shows or play mobile games. Thanks to various applications, these devices can also be used for practicing sports and physical activity (e.g. measuring pulse, counting steps), reading magazines and books and many other activities (Nwagwu, Famiyesin, 2016). Mobile devices, i.e. omnipresent smartphones, are now portable computers which fit into almost every pocket and their widespread use is also related to the fact that they are more affordable than laptops for the average consumer (Okazaki, Mendez, 2013; Suki, 2013; Kim et al., 2016).

The widespread use of mobile devices is also related to their application in SNS communication. This type of communication can be termed m-communication (mobile communication). In relation to the above analysis mobile devices are also used for searching for and conveying information about products via SNSs. To reiterate, one of the initial research questions refers to the interdependence between the frequency of exchanging information about products via SNSs and the type of device used for such exchange.

In order to answer the research question, a third hypothesis $\left(\mathrm{H}_{3}\right)$ can be formulated, that: the type of device used, influences communication based on exchanging information about products among SNSs' users. 


\section{Methodology}

\subsection{Measurement development and data collection}

Methodologically, this paper takes a deductive approach, given that the aim is to verify the hypotheses formulated on the basis of the findings of other researchers. In the exploratory empirical study the authors used two research methods: PAPI (Paper and Pen Personal Interview) and CAWI (Computer Assisted Web Interview). Firstly, in order to collect fast responses, the author used CAWI with an online questionnaire, which was filled in by the respondents. The main advantage of the CAWI method is that it saves time and cost (no paper or distribution cost) in comparison with the PAPI method. However, the use of an online questionnaire has not produced great feedback and constitutes only $3.5 \%$ of all collected questionnaires. Secondly, the author decided to use PAPI method in each market, which is more expansive and time consuming but it gave better results in the case of presented research.

The measurement instrument was a standardized questionnaire prepared for the purpose of this research. The element differentiating the research questionnaire in particular markets was the language. In Poland the Polish language was used, in China Chinese, in Turkey Turkish and in the American market English. In the preparation of the different versions of the questionnaire a back translation procedure was used in order to eliminate any mistakes stemming from linguistic, lexical or context differences.

The empirical data was gathered in 2016 and the total number of respondents surveyed in the four countries was 1246 (295 respondents from China, 296 from Poland, 395 from Turkey and 260 from United States). The United States, Poland, Turkey and China form a kind of bridge through the world and they are differentiated markets according to Internet, mobile, and social media usage. Besides, these markets are interesting for Polish companies because of their potential and the Polish companies' involvement in them. The data was collected by non-random sampling (convenience sampling method) and designated research assistants gathered the questionnaires from the respondents in each market.

The differences in size between the researched groups and the sampling method that was applied, influence the interpretation of the obtained results which, in this case, should not be generalized for the population of particular countries.

\subsection{Respondent profile}

The surveyed respondents in each country had all agreed to participate and stated that they were willing to describe the ways in which they use SNSs for work activities. The study was conducted among people of all ages and three age groups were 
distinguished: 15-20, 21-30, 31 or more (Table 1). In China, Poland and Turkey the respondents within the 21-30 age group were most numerous, whereas in the United States most participants belonged to the 15-20 age group. The smallest number of respondents was observed in the age group of 31 and more.

Table 1. Respondent profile (\%)

\begin{tabular}{|l|c|c|c|c|}
\hline & China & Poland & United States & Turkey \\
\hline \multicolumn{5}{|c|}{ GENDER } \\
\hline Women & 68.1 & 70.9 & 56.5 & 48.7 \\
\hline Men & 31.2 & 27.7 & 43.1 & 49.7 \\
\hline No data & 0.7 & 1.3 & 0.4 & 1.5 \\
\hline \multicolumn{5}{|c|}{ AGE } \\
\hline 15-20 years & 14.2 & 35.5 & 79.6 & 9.6 \\
\hline 21-30 years & 66.4 & 63.5 & 16.9 & 76.5 \\
\hline 31 years and more & 19 & 0.7 & 3.5 & 13.4 \\
\hline
\end{tabular}

Source: own research

Taking into account the diversity of the study group in terms of gender it should be emphasized that it is difficult to determine whether there is a significant dominance of any gender. In two countries gender parity in respondents was almost reached, e.g. the United States and Turkey). In the other two, China and Poland, a vast majority of users were women.

\subsection{Operationalisation of variables}

Variables were operationalized in three ways. Firstly, for checking the validation of $\mathrm{H}_{1}$ a Kruskal-Wallis test was performed in order to identify whether there were differences among cultures in the method of communication via SNSs $\left(\mathrm{C}_{1}, \mathrm{C}_{2}, \mathrm{C}_{3}\right.$, $\mathrm{C}_{4}, \mathrm{C}_{5}$ ). During the pilot research conducted by the authors, the respondents predominately pointed to the use of SNSs according to: searching for information about different products $\left(\mathrm{C}_{1}\right)$; asking friends/acquaintances for advice concerning the purchase of products $\left(\mathrm{C}_{2}\right)$; asking other people (not only acquaintances) for advice concerning the purchase of products or brands $\left(\mathrm{C}_{3}\right)$; recommending various products to other users, which in their opinion were worth buying $\left(\mathrm{C}_{4}\right)$; and placing appropriate information when the product they bought turned out to be of very low quality $\left(\mathrm{C}_{5}\right) . \mathrm{C}_{1}$, $\ldots, \mathrm{C}_{5}$ refer to types of communication via SNSs (gathering and exchanging information about products). These were identified during the test research, where consumers indicated these activities as the most frequently performed via SNSs.

Secondly, to examine the relations between $\mathrm{C}_{1}, \mathrm{C}_{2}, \mathrm{C}_{3}, \mathrm{C}_{4}, \mathrm{C}_{5}$ and product categories, statistical Spearman indicators showing the interdependence/or its lack 
were analysed $\left(\mathrm{H}_{2}\right)$. The following categories of products and services were assessed: mobile phones $\left(\mathrm{P}_{1}\right)$, computers - laptops, tablets $\left(\mathrm{P}_{2}\right)$; cars $\left(\mathrm{P}_{3}\right)$; cosmetics $\left(\mathrm{P}_{4}\right)$ and fashion - clothes and shoes (P5). The product categories were established on the basis of literature review findings. Thirdly, Spearman correlation was used for identification of the relationship between devices - desktop/laptop $\left(\mathrm{D}_{1}\right)$, smartphone $\left(\mathrm{D}_{2}\right)$, tablet $\left(\mathrm{D}_{3}\right)$ (Wong, 2011) - SNS usage and the method of communication $\left(\mathrm{C}_{1}, \mathrm{C}_{2}, \mathrm{C}_{3}, \mathrm{C}_{4}, \mathrm{C}_{5}\right)\left(\mathrm{H}_{3}\right)$. The relationship between frequency of device $\left(\mathrm{D}_{1}, \mathrm{D}_{2}\right.$, $\left.\mathrm{D}_{3}\right)$ usage and the category of products $\left(\mathrm{P}_{1}, \mathrm{P}_{2}, \mathrm{P}_{3}, \mathrm{P}_{4}, \mathrm{P}_{5}\right)$ was also tested for.

In order to identify communication activities, the respondents were asked to specify the frequency at which they performed them (very often -1 , often -2 , from time to time -3 , rarely -4 , very rarely -5 , never -6 ) for particular statements $\left(\mathrm{C}_{1}, \ldots, \mathrm{C}_{5}\right)$. Cronbach's Alpha was used (Table 2$)$ for reliability analysis. Cronbach Alpha results confirmed that the proposed scale was a reliable tool for measuring.

Table 2. Cronbach's alpha correlation

\begin{tabular}{|l|c|}
\hline \multicolumn{1}{|c|}{ Variables } & Cronbach's Alpha \\
\hline Communication (C) & 0.779 \\
Products (P) & 0.708 \\
Devices (D) & 0.722 \\
\hline
\end{tabular}

Source: own research

\section{Results}

In order to examine whether the respondents from the researched countries differed among each other in terms of the frequency of use of SNSs to exchange information about products, an analysis was performed with the use of a Kruskal-Wallis test (Table 3).

The analyses showed statistically significant differences among the studied groups. For searching for information about various products $\left(C_{1}\right): H(3$, $N=1176)=36.29 ; p<0.001$ multiple comparisons demonstrated that people living in Turkey used SNSs in order to look for information more often than people living in Poland $(p<0.001)$, China $(p=0.002)$ and the United States $(p<0.001)$.

For asking friends/acquaintances for advice concerning purchase of a particular product $\left(\mathrm{C}_{2}\right): \mathrm{H}(3, N=1181)=36.88 ; p<0.001$, Kruskal-Wallis analysis showed that the respondents from the United States used SNSs less often than the respondents from Poland $(p<0.001)$, China $(p<0.001)$ and Turkey $(p<0.001)$.

For asking other people (not only friends/acquaintances) for advice concerning purchase of a particular product or brand $\left(\mathrm{C}_{3}\right): \mathrm{H}(3, N=1190)=69.28 ; p<0.001$ multiple comparisons showed that the respondents from China used SNSs more often than Polish $(p<0.001)$, Turkish $(p<0.001)$ and American $(p<0.001)$ respondents. 
Table 3. Kuskal-Wallis test for SNSs usage for communication about products in researched countries

\begin{tabular}{|c|c|c|c|c|c|c|c|}
\hline $\begin{array}{c}\text { Sign } \\
\text { of activity }\end{array}$ & Country & $\begin{array}{c}\text { Number } \\
\text { of respondents }\end{array}$ & Mean & $\begin{array}{l}\text { Standard } \\
\text { deviation }\end{array}$ & $\begin{array}{c}\text { Medium } \\
\text { rank }\end{array}$ & \begin{tabular}{|c|} 
Result \\
of Kruskal-Wallis \\
test
\end{tabular} & $\begin{array}{c}\text { Level } \\
\text { of significance } \\
\text { for } \mathrm{K}-\mathrm{W} \text { test }\end{array}$ \\
\hline \multirow{4}{*}{$\mathrm{C}_{1}$} & Poland & 280 & 3.44 & 1.54 & 647 & \multirow{4}{*}{36.29} & \multirow{4}{*}{$<0.001$} \\
\hline & China & 277 & 3.20 & 1.47 & 601 & & \\
\hline & Turkey & 363 & 2.81 & 1.45 & 504 & & \\
\hline & US & 256 & 3.36 & 1.54 & 630 & & \\
\hline \multirow{4}{*}{$\mathrm{C}_{2}$} & Poland & 276 & 3.50 & 1.53 & 570 & \multirow{4}{*}{36.88} & \multirow{4}{*}{$<0.001$} \\
\hline & China & 277 & 3.39 & 1.46 & 548 & & \\
\hline & Turkey & 369 & 3.48 & 1.59 & 561 & & \\
\hline & US & 259 & 4.11 & 1.53 & 702 & & \\
\hline \multirow{4}{*}{$\mathrm{C}_{3}$} & Poland & 281 & 3.98 & 1.59 & 598 & \multirow{4}{*}{69.28} & \multirow{4}{*}{$<0.001$} \\
\hline & China & 281 & 3.40 & 1.43 & 472 & & \\
\hline & Turkey & 368 & 4.01 & 1.68 & 605 & & \\
\hline & US & 260 & 4.51 & 1.45 & 712 & & \\
\hline \multirow{4}{*}{$\mathrm{C}_{4}$} & Poland & 287 & 4.27 & 1.55 & 615 & \multirow{4}{*}{41.30} & \multirow{4}{*}{$<0.001$} \\
\hline & China & 278 & 3.85 & 1.51 & 515 & & \\
\hline & Turkey & 368 & 4.07 & 1.61 & 564 & & \\
\hline & US & 259 & 4.63 & 1.54 & 693 & & \\
\hline \multirow{4}{*}{$\mathrm{C}_{5}$} & Poland & 282 & 4.29 & 1.50 & 651 & \multirow{4}{*}{131.30} & \multirow{4}{*}{$<0.001$} \\
\hline & China & 278 & 3.15 & 1.64 & 433 & & \\
\hline & Turkey & 366 & 3.81 & 1.71 & 560 & & \\
\hline & US & 259 & 4.75 & 1.56 & 749 & & \\
\hline
\end{tabular}

Source: own research

For recommending various products, which are worth buying, to other users $\left(\mathrm{C}_{4}\right): \mathrm{H}(3, N=1192)=41.30 ; p<0.001$ Kruskal-Wallis analysis showed that the respondents from the United States used SNSs less often than people living in Poland $(p<0.001)$, China $(p<0.001)$ and Turkey $(\mathrm{p}=0.030)$.

For warning others whether the product that had been bought had been of a very low quality $\left(\mathrm{C}_{5}\right): \mathrm{H}(3, N=1185)=131.30 ; p<0.001$ multiple comparisons demonstrated that respondents from the United States use SNSs less often than people living in Poland $(p=0.005)$, China $(p<0.001)$ and Turkey $(p<0.001)$.

The respondents from China and Turkey use SNSs to the greatest degree both for gathering, as well as conveying information about products. On the other hand, the American respondents were least likely to do so. The above analysis makes it possible to state that $\mathrm{H}_{1}$, which claimed that there are differences among users from the researched countries in using SNSs for communication, which are based on exchanging information about products, is true. 
Table 4. Relationships between communication via SNSs and the type of product - Spearman correlation*

\begin{tabular}{|c|c|c|c|c|c|}
\hline \multirow{2}{*}{ Communication } & \multirow{2}{*}{$\begin{array}{l}\text { Products/ } \\
\text { Symbol }\end{array}$} & China & Poland & United States & Turkey \\
\hline & & $R$ & $R$ & $R$ & $R$ \\
\hline \multirow{5}{*}{$\mathrm{C}_{1}$} & $\mathrm{P}_{1}$ & 0.280 & 0.214 & 0.216 & 0.145 \\
\hline & $\mathrm{P}_{2}$ & 0.311 & 0.369 & 0.385 & 0.379 \\
\hline & $\mathrm{P}_{3}$ & 0.240 & 0.191 & 0.273 & 0.160 \\
\hline & $\mathrm{P}_{4}$ & 0.250 & 0.400 & 0.311 & 0.282 \\
\hline & $\mathrm{P}_{5}$ & 0.391 & 0.422 & 0.444 & 0.388 \\
\hline \multirow{5}{*}{$\mathrm{C}_{2}$} & $\mathrm{P}_{1}$ & 0.255 & 0.189 & 0.236 & 0.236 \\
\hline & $\mathrm{P}_{2}$ & 0.236 & 0.257 & 0.262 & 0.239 \\
\hline & $\mathrm{P}_{3}$ & 0.208 & 0.223 & 0.229 & 0.157 \\
\hline & $\mathrm{P}_{4}$ & 0.372 & 0.275 & 0.224 & 0.240 \\
\hline & $\mathrm{P}_{5}$ & 0.306 & 0.361 & 0.377 & 0.386 \\
\hline \multirow{5}{*}{$\mathrm{C}_{3}$} & $\mathrm{P}_{1}$ & 0.216 & 0.220 & 0.259 & 0.288 \\
\hline & $\mathrm{P}_{2}$ & 0.271 & 0.272 & 0.267 & 0.289 \\
\hline & $\mathrm{P}_{3}$ & 0.290 & 0.173 & 0.290 & 0.205 \\
\hline & $\mathrm{P}_{4}$ & 0.213 & 0.235 & 0.217 & 0.123 \\
\hline & $\mathrm{P}_{5}$ & 0.256 & 0.226 & 0.211 & 0.177 \\
\hline \multirow{5}{*}{$\mathrm{C}_{4}$} & $P_{1}$ & 0.224 & 0.233 & 0.215 & 0.261 \\
\hline & $\mathrm{P}_{2}$ & 0.249 & 0.284 & 0.232 & 0.245 \\
\hline & $P_{3}$ & 0.213 & 0.225 & 0.258 & 0.206 \\
\hline & $\mathrm{P}_{4}$ & 0.222 & 0.223 & 0.180 & 0.298 \\
\hline & $\mathrm{P}_{5}$ & 0.254 & 0.330 & 0.388 & 0.231 \\
\hline \multirow{5}{*}{$\mathrm{C}_{5}$} & $\mathrm{P}_{1}$ & 0.310 & 0.360 & 0.324 & 0.367 \\
\hline & $\mathrm{P}_{2}$ & 0.256 & 0.426 & 0.144 & 0.234 \\
\hline & $\mathrm{P}_{3}$ & 0.271 & 0.281 & 0.242 & 0.245 \\
\hline & $\mathrm{P}_{4}$ & 0.275 & 0.270 & 0.176 & 0.177 \\
\hline & $\mathrm{P}_{5}$ & 0.229 & 0.277 & 0.205 & 0.197 \\
\hline
\end{tabular}

$R$ - Spearman correlation.

* Correlation is significant at the $p<0.05$ level.

Source: own research

Referring to the measurement of interdependencies between $\mathrm{C}_{1}, \ldots, \mathrm{C}_{5}$ and a type of product, Spearman correlation coefficients showed that there were statistically significant relationships $(p<0.05)$ between all means of exchanging information about products and types of products (Table 4). However, the level of these indicators denotes the strength of the relation: the higher the Spearman coefficient, the stronger the relationship $R=[-1 ; 1]$. Regardless of the country, the studied respondents most often look for information via SNSs $\left(\mathrm{C}_{1}\right)$ about electronic goods $\left(\mathrm{P}_{2}\right)$ as well as clothes and footwear $\left(\mathrm{P}_{5}\right)$. In the Polish and American groups, information about cosmetics was also often gathered via SNSs. If they sought advice from their friends about buy- 
ing a product $\left(\mathrm{C}_{2}\right)$, respondents most often asked about clothes and footwear $\left(\mathrm{P}_{5}\right)$, and in the Chinese group, also cosmetics $\left(\mathrm{P}_{4}\right)$.

Respondents in all countries rarely sought advice from other SNS users about buying particular products $\left(\mathrm{C}_{3}\right)$. The level of Spearman correlation coefficients was noted here as $R<0.3$, and was therefore weak. The respondents also did not often recommend valuable products via SNSs $\left(\mathrm{C}_{4}\right)$. Only in the Polish and American groups the correlation was $R>0.3$ as far as clothes and footwear $\left(\mathrm{P}_{5}\right)$ are concerned. They would more often warn others if the phone $\left(\mathrm{C}_{5}, \mathrm{P}_{2}\right)$, and electronic goods in the Polish group $\left(\mathrm{C}_{5}, \mathrm{P}_{2}\right)$, turned out to be poor quality. Analysis of the obtained results indicate that hypothesis $2\left(\mathrm{H}_{2}\right)$, stating that the users most often exchange information via SNSs about electronic goods, clothes and shoes, is true.

Table 5. Relationships between communication via SNSs and the type of device used - Spearman correlation

\begin{tabular}{|c|c|c|c|c|c|}
\hline \multirow{2}{*}{ Communication } & \multirow{2}{*}{ Devices } & China & Poland & Turkey & United States \\
\hline & & $R$ & $R$ & $R$ & $R$ \\
\hline \multirow{3}{*}{$\mathrm{C}_{1}$} & $\mathrm{D}_{1}$ & $0.232 * *$ & 0.078 & 0.067 & 0.115 \\
\hline & $\mathrm{D}_{2}$ & $0.147^{* *}$ & $0.124^{*}$ & $0.205^{*}$ & $0.254 * *$ \\
\hline & $\mathrm{D}_{3}$ & $0.179 * *$ & $0.192 *$ & 0.06 & $0.129 *$ \\
\hline \multirow{3}{*}{$\mathrm{C}_{2}$} & $\mathrm{D}_{1}$ & $0.214 * *$ & 0.078 & 0.051 & 0.122 \\
\hline & $\mathrm{D}_{2}$ & $0.158 * *$ & $0.119 *$ & $0.172 *$ & $0.200 * *$ \\
\hline & $\mathrm{D}_{3}$ & 0.065 & $0.182 *$ & 0.082 & 0.065 \\
\hline \multirow{3}{*}{$\mathrm{C}_{3}$} & $\mathrm{D}_{1}$ & $0.185^{* *}$ & 0.032 & 0.095 & 0.105 \\
\hline & $\mathrm{D}_{2}$ & $0.129 * *$ & $0.137 *$ & 0.030 & $0.208 * *$ \\
\hline & $\mathrm{D}_{3}$ & 0.102 & 0.065 & 0.04 & 0.115 \\
\hline \multirow{3}{*}{$\mathrm{C}_{4}$} & $\mathrm{D}_{1}$ & $0.156 * *$ & 0.132* & 0.037 & 0.120 \\
\hline & $\mathrm{D}_{2}$ & $0.134 *$ & $0.133 *$ & $0.140 *$ & $0.152 *$ \\
\hline & $\mathrm{D}_{3}$ & 0.105 & 0.09 & 0.015 & 0.039 \\
\hline \multirow{3}{*}{$\mathrm{C}_{5}$} & $\mathrm{D}_{1}$ & 0.108 & 0.112 & -0.018 & 0.056 \\
\hline & $\mathrm{D}_{2}$ & 0.069 & 0.016 & 0.120 & 0.1 \\
\hline & $\mathrm{D}_{3}$ & 0.04 & 0.110 & 0.118 & 0.05 \\
\hline
\end{tabular}

$R$ - Spearman correlation.

* Correlation is significant at the level of $p<0.05$.

** Correlation is significant at the level of $p<0.01$.

\section{Source: own research}

When it comes to the nature of communication for exchanging information about products among SNS users, it is clear that mobile devices, such as smart- 
phones, are preferred (Table 5) and the analysis shows the greatest number of statistically significant correlations for these devices $(p<0.05$ and $p<0.01)$. In all the researched groups, the more often the respondents used smartphones, the more often they looked for information about products $\left(\mathrm{C}_{1}\right)$, sought advice from friends and other SNSs users $\left(\mathrm{C}_{2}, \mathrm{C}_{3}\right)$, and recommended valuable goods $\left(\mathrm{C}_{4}\right)$. In relation to $\mathrm{C}_{5}$ no statistically significant correlation was noted.

The high significance of desktop computers/laptops in the Chinese group also needs to be emphasized. Moreover, Spearman coefficient values for the Chinese group are higher in the case of desktop computers/laptops than smartphones. This indicates that there are much closer relationships between these devices and gathering and conveying information about products. Furthermore, using tablets is more often related to searching for information $\left(\mathrm{C}_{1}\right)$ in the Chinese, Polish and American groups.

Table 6. Relationships between the type of device used and the category of product - Spearman correlation

\begin{tabular}{|c|c|c|c|c|c|}
\hline \multirow{2}{*}{$\begin{array}{c}\text { Type } \\
\text { of product }\end{array}$} & \multirow{2}{*}{ Device } & China & Poland & Turkey & United States \\
\hline & & $\boldsymbol{R}$ & $\boldsymbol{R}$ & $\boldsymbol{R}$ & $\boldsymbol{R}$ \\
\hline \multirow{3}{*}{$\mathrm{P}_{1}$} & $\mathrm{D}_{1}$ & 0.089 & 0.035 & $0.140 * *$ & 0.104 \\
\hline & $\mathrm{D}_{2}$ & $0.169 * *$ & $0.169 * *$ & $0.197 *$ & $0.212 * *$ \\
\hline & $\mathrm{D}_{3}$ & $0.130 *$ & $0.177 * *$ & 0.094 & $0.164 * *$ \\
\hline \multirow{3}{*}{$\mathrm{P}_{2}$} & $\mathrm{D}_{1}$ & $0.126^{*}$ & 0.042 & $0.239 * *$ & $0.218^{*}$ \\
\hline & $\mathrm{D}_{2}$ & $0.150 * *$ & 0.061 & 0.104 & $0.210 * *$ \\
\hline & $\mathrm{D}_{3}$ & $0.138 *$ & $0.190 * *$ & $0.127 *$ & $0.128 *$ \\
\hline \multirow{3}{*}{$\mathrm{P}_{3}$} & $D_{1}$ & 0.098 & -0.03 & 0.024 & 0.057 \\
\hline & $\mathrm{D}_{2}$ & 0.059 & 0.037 & 0.103 & 0.117 \\
\hline & $\mathrm{D}_{3}$ & $0.194 * *$ & 0.108 & $0.165 *$ & $0.124 *$ \\
\hline \multirow{3}{*}{$\mathrm{P}_{4}$} & $\mathrm{D}_{1}$ & 0.135* & 0.028 & -0.042 & 0.099 \\
\hline & $\mathrm{D}_{2}$ & 0.103 & $0.199 * *$ & $0.142 * *$ & $0.256 * *$ \\
\hline & $\mathrm{D}_{3}$ & 0.064 & $0.127 *$ & $0.177 * *$ & $0.147 *$ \\
\hline \multirow{3}{*}{$\mathrm{P}_{5}$} & $\mathrm{D}_{1}$ & $0.144 *$ & 0.062 & -0.092 & $0.242 * *$ \\
\hline & $\mathrm{D}_{2}$ & 0.134* & $0.155 * *$ & $0.164 * *$ & $0.303 * *$ \\
\hline & $\mathrm{D}_{3}$ & $0.145 *$ & 0.103 & $0.195 *$ & 0.164* \\
\hline
\end{tabular}

$R$ - Spearman correlation.

* Correlation is significant at the level of $p<0.05$.

** Correlation is significant at the level of $p<0.01$.

Source: own research

When comparing relationships between devices and the nature of communication via SNSs, the prevalence of smartphones and tablets (mobile devices) is obvious. Analysis of these correlations via Spearman coefficients showed that the third hypothesis $\left(\mathrm{H}_{3}\right)$, that a type of a device used, influences communication based on exchanging information about products among SNSS users, is true. 
Additionally, Spearman correlation coefficients were also used in order to identify detailed relationships between the type of device used and the frequency of looking for information about products via SNSs (Table 6). The results confirm the above statements regarding the high significance of mobile devices in terms of using SNSs to search for information about mobile phones, electronic goods, clothes and shoes as well as cosmetics. The least interesting were cars, which may stem from the fact that most respondents were of a young age. It is also worth highlighting that statistically significant correlations were also noted in the Chinese, Turkish and American groups in relation to desktop computers, as well as $\mathrm{P}_{1}, \mathrm{P}_{2}, \mathrm{P}_{4}$ and $\mathrm{P}_{5}$.

\section{Discussion and implications}

The Kruskal-Wallis analysis demonstrated differences among the studied groups in relation to the frequency of gathering and conveying information about products to SNSs users. This is most often done by the respondents from China and Turkey, while American respondents do this least often. These results show a convergence with cultural traits described as collectivistic and individualistic (Hofstede, Hofstede, Minkov, 2010). According to Hofstede's studies, Turkey and China are collectivistic countries $\left(\operatorname{IDV}_{\text {China }}=20, \operatorname{IDV}_{\text {Turkey }}=37\right)$ where behaviours focused on the group and not the achievements of an individual dominate (Hofstede, Hofstede, Minkov, 2010). These characteristics were the basis for creating SNSs, thus networks of friends, exchanging and looking for information, etc. This is why the usage of SNSs for exchanging information about products is the most frequent in these countries. On the other hand people from individualistic cultures make individual decisions without the necessity to gather information or use advice from others. The highest level of individualism was found in the American group $\left(\mathrm{IDV}_{\mathrm{US}}=91\right)$. That is why the usage of SNSs for exchanging information about products is very rare there. The research confirms the earlier interdependencies distinguished by other researchers, that people from collectivistic countries use relationships established via SNSs to gain information about products (Tsai, Men, 2012; Hsu et al., 2015). The frequency of searching for information about products among friends via SNSs also indicates such behaviour.

In summary, it should be stated that Internet users, especially younger users, like and appreciate mobile technology (Skokan, 2016). Many young recipients cannot be now reached through traditional channels of communication and they can be found less and less frequently in front of their computers. Optimizing all activities in terms of mobile devices - from the distribution of content and its formats, to the process of selling, will be a challenge. This is confirmed by the statistics of the mobile industry where largescale usage of mobile devices (i.e. smartphones 
and tablets) and m-communication has been noted (Tan, Goh, 2015). This has also been confirmed by the above research in four culturally different countries. What is interesting and surprising in the Chinese group, is that statistically significant, or even stronger (in comparison to $\mathrm{D}_{2}$ ), correlations in relation to desktop computers $\left(D_{1}\right)$ were observed, showing that the Chinese use SNSs on desktop computers more often than on smartphones. This information can be of great importance for the designers of both SNSs and other mobile applications (Nwagwu, Famiyesin, 2016). Enterprises that use SNSs for marketing communication should consider, and invest in, mobile versions of their websites (Banerjee, Dholakia, 2012), as well as create mobile applications that can be used for marketing activities in foreign markets. Such apps are likely to be used by producers and sellers of electronic goods, mobile phones and manufacturers of clothes and footwear. The studies showed that the supporters of mobile devices most often search for information about these particular products via SNSs. Given the findings on the extent to which young consumers exchange information about products, applications regarding products targeted at young buyers should be of particular interest (Banerjee, Dholakia, 2012). An emerging trend among mobile applications is the development of various functions in mobile-only instant messaging apps such as Messenger, WhatsApp, WeChat, and Viber (Kim et al., 2016). These apps can now be used to order a taxi, pay for a service or order chosen products.

The results of the study also point to opportunities for the producers of particular goods such as electronic goods, mobile phones, cosmetics, and in particular clothes and footwear, when applying mobile advertising. An advertisement should be placed where its potential recipient will view it (Kim et al., 2016; Nwagwu, Famiyesin, 2016).

\section{References}

Andersen L.P., Tufte B., Rasmussen J., Chan K. (2007), Tweens and new media in Denmark and Hong Kong, "Journal of Consumer Marketing", vol. 24, issue 6, pp. 340-350.

Banerjee S., Dholakia R.R. (2012), Location-based mobile advertisements and gender targeting, "Journal of Research in Interactive Marketing", vol. 6, issue 3, pp. 198-214.

Boateng R. (2011), Mobile phones and micro-trading activities - conceptualizing the link, info, "Journal for Policy, Regulation and Strategy", vol. 13, issue 5, pp. 48-62.

Borrero J.D., Yousafzai S.Y., Javed U., Page K.L. (2014), Perceived value of social networking sites (SNS) in students' expressive participation in social movements, "Journal of Research in Interactive Marketing", vol. 8, issue 1, pp. 56-78.

Carayannis E.G., Clark S.C., Valvi D.E. (2012), Smartphone affordance: achieving better business through innovation, "Journal of the Knowledge Economy", vol. 22, no. 6, pp. 1-11.

Davies J., Musango J.K., Brent A.C. (2016), A systems approach to understanding the effect of Facebook use on the quality of interpersonal communication, "Technology in Society", no. 44, pp. 55-65. 
Erkan I., Evans Ch. (2016), The influence of eWOM in social media on consumers' purchase intentions: An extended approach to information adoption, "Computers in Human Behavior", no. 61, pp. $47-55$.

Fong J., Burton S. (2008), A cross cultural comparison of electronic word-of-mouth and country-of-origin effects, "Journal of Business Research", no. 61, pp. 233-242.

Geissinger A., Laurell Ch. (2016), User engagement in social media - an explorative study of Swedish fashion brands, "Journal of Fashion Marketing and Management", vol. 20, issue 2, pp. 177-190.

Habibi M.R., Laroche M., Richard M.O. (2016), Testing an extended model of consumer behavior in the context of social media-based brand communities, "Computers in Human Behavior", no. 62 , pp. 292-302.

Hansen T., Jensen J.M. (2009), Shopping orientation and online clothing purchases: the role of gender and purchase situation, "European Journal of Management", vol. 43, no. 9/10, pp. 1154-1170.

Hofstede G., Hofstede G.J., Minkov M. (2010), Cultures and Organizations: Software of the Mind, McGraw-Hill, New York.

Hsu M.H., Tien S.W., Lin H.Ch., Chang Ch.M. (2015), Understanding the roles of cultural differences and socio-economic status in social media continuance intention, "Information Technology \& People", vol. 28, no. 1, pp. 224-241.

Kaplan A.M., Haenlein M. (2010), Users of the world, unite! The challenges and opportunities of social media, "Business Horizons", vol. 53, pp. 59-68.

Kaplan A.M., Haenlein M. (2011), Two hearts in three-quarter time: How to waltz the social media/viral marketing dance, "Business Horizons", vol. 54, pp. 253-263.

Kemp S. (2016), Digital in 2016 report: We Are Social's, 27 January 2016, http://wearesocial.com/ uk/special-reports/digital-in-2016 [accessed: 3.12.2016].

Kim S., Baek T.H., Kim Y.K., Yoo K. (2016), Factors affecting stickiness and word of mouth in mobile applications, "Journal of Research in Interactive Marketing", vol. 10, issue 3, pp. 177-192.

Lin K.Y., Lu H.P. (2015), Predicting mobile social network acceptance based on mobile value and social influence, "Internet Research", vol. 25, issue 1, pp. 107-130.

Nwagwu W.E., Famiyesin B. (2016), Acceptance of mobile advertising by consumers in public service institutions in Lagos, Nigeria, "The Electronic Library", vol. 34, issue 2, pp. 265-288.

Okazaki S., Mendez F. (2013), Perceived ubiquity in mobile services, "Journal of Interactive Marketing", vol. 27, no. 2, pp. 98-111.

Persaud A., Azhar I. (2012), Innovative mobile marketing via smartphones: are consumers ready?, "Marketing Intelligence and Planning", vol. 30, no. 4, pp. 3-36.

Ray D. (2014), Overcoming cross-cultural barriers to knowledge management using social media, "Journal of Enterprise Information Management", vol. 27, no. 1, pp. 45-55.

Ryan T., Xenos S. (2011), Who uses Facebook? An investigation into the relationship between the Big Five, shyness, narcissism, loneliness, and Facebook usage, "Computers in Human Behavior", vol. 27, no. 5, pp. 1658-1664.

Shephard A., Pookulangara S., Kinley T.R., Josiam B.M. (2016), Media influence, fashion, and shopping: a gender perspective, "Journal of Fashion Marketing and Management", vol. 20, issue 1, pp. 4-18.

Skokan I. (2016), Jak zmierzyć ruch z urządzeń mobilnych, "Nowy Marketing", 30.08.2016, http:// nowymarketing.pl/a/10684,jak-zmierzyc-ruch-z-urzadzen-mobilnych?h=112524 [accessed: 23.01.2017].

Smith P.R., Zook Z. (2011), Marketing Communications: Integrating Offline and Online with Social Media, Kogan Page Publ., London. 
Statista.com (2012), Most popular categories purchased on Pinterest in March 2012, http://www. statista.com/statistics/251053/most-popular-categories-purchased-on-pinterest [accessed: 20.01.2017].

Suki N.M. (2013), Students' dependence on smart phones, "Campus-Wide Information Systems", vol. 30, issue 2, pp. 124-134.

Tan E.M.Y., Goh D.H.L. (2015), Presenting social media information on mobile devices using multiple contexts, "Aslib Journal of Information Management", vol. 67, issue 2, pp. 18-202.

Tojib D., Tsarenko Y. (2012), Post-adoption modelling of advanced mobile service use, "Journal of Business Research", vol. 62, no. 7, pp. 922-928.

Tsai W.H., Men L.R. (2012), Cultural values reflected in corporate pages on popular social network sites in China and the United States, "Journal of Research in Interactive Marketing", vol. 6, issue 1, pp. 42-58.

Wallace E., Buil E., De Chernatony L. (2014), Consumer engagement with self-expressive brands: brand love and WOM outcomes, "Journal of Product \& Brand Management", vol. 23, no. 1, pp. 33-42.

Walther J.B. (1996), Computer-Mediated Communication. Impersonal, Interpersonal, and Hyperpersonal Interaction, "Communication Research", vol. 23, no. 1, pp. 3-43.

Wong S.H.R. (2011), Which platform do our users prefer: website or mobile app?, "Journal of Reference Services Review", vol. 40, no. 1, pp. 103-115.

\section{Komunikacja mobilna w wymianie informacji o produktach - porównanie międzynarodowe}

Streszczenie: Głównym celem artykułu jest identyfikacja stopnia wykorzystania serwisów społecznościowych w komunikacji związanej z gromadzeniem informacji o produktach przy zastosowaniu urządzeń mobilnych (komunikacja mobilna). Problem badawczy został przedstawiony w świetle teorii komunikacji internetowej. W realizacji celu głównego dokonano próby odpowiedzi na dwa pytania badawcze: po pierwsze, czy istnieje związek między rodzajami produktów a częstotliwością gromadzenia i przekazywania informacji o produktach za pośrednictwem serwisów społecznościowych, po drugie, jaką rolę w tej komunikacji odgrywają urządzenia mobilne. Studia literaturowe zostały uzupełnione badaniami empirycznymi, które przeprowadzono w czterech krajach - Chinach, Polsce, Stanach Zjednoczonych oraz Turcji. W badaniach empirycznych wykorzystano dwie metody badawcze: PAPI (Paper and Pen Personal Interview) i CAWI (Computer Assisted Web Interview). Badania empiryczne pokazały duże wykorzystanie urządzeń mobilnych (tj. smartfonów oraz tabletów) w komunikacji (gromadzeniu i poszukiwaniu informacji o produktach) za pośrednictwem serwisów społecznościowych, szczególnie w odniesieniu do takich produktów jak urządzenia elektroniczne, a także odzież i obuwie.

Słowa kluczowe: komunikacja mobilna, teoria komunikacji internetowej, serwisy społecznościowe JEL: M31, M37, M21

\begin{tabular}{|l|l|}
\hline \multirow{2}{*}{ OPEN ACCESS } & $\begin{array}{l}\text { C by the author, licensee Łódź University - Łódź University Press, Łódź, Poland. } \\
\text { This article is an open access article distributed under the terms and conditions } \\
\text { of the Creative Commons Attribution license CC-BY } \\
\text { (http: //creativecommons.org/licenses/by/3.0/) }\end{array}$ \\
\cline { 2 - 2 } & Received: 2017-07-01; verified: 2017-11-22. Accepted: 2018-01-18 \\
\hline
\end{tabular}

